\title{
Developing Academic Writing Module to Reduce Plagiarism
}

\author{
Hilma Suryani ${ }^{1}$, Eka Apriani ${ }^{2}$
}

DOI: $10.35445 /$ alishlah.v13i3.791

\begin{abstract}
Article Info
Abstract

Keywords:

Citation,

Module,

Plagiarism,

Research and

development

Plagiarism has become a stressful problem in the academic world. In higher education, students must write a scientific paper that is free from plagiarism. Many referencing styles are offered to enable the writers to produce the proper scientific works. This study aimed to produce a module on academic writing for English department students. The module focused on writing citations based on APA style references, including in-text citation, paraphrasing, and summarizing. It was a research and development study that involved fifthsemester students. The samples were selected purposively. The data were collected by using interviews, questionnaires, and tests to see the product's validity, practicality, and effectiveness. The data gathered were analyzed qualitatively and quantitatively. Based on the study results, it was found that the validity of the product showed a very high category (0.92). Practicality consists of three aspects, ease, efficiency, and usefulness, categorized very high at small groups (0.85) and field tests (o.87). The module's effectiveness was seen from the gain score, which is 0.4 . This score indicated the medium progress made by the students after having the treatment.
\end{abstract}

Kata kunci:

Sitasi,

Modul,

Plagiarism,

Riset pengembangan

\begin{abstract}
Abstrak
Plagiarisme merupakan permasalahan yang kerapkali muncul dalam dunia pendidikan. Mahasiswa diharuskan untuk menulis karya ilmiah yang bebas dari plagiarisme. Beragam cara pengutipan diberikan agar mahasiswa dapat menghasilkan karya ilmiah yang tepat. Penelitian ini bertujuan untuk mengembangkan modul Academic Writing untuk mahasiswa Program Studi Bahasa Inggris. Modul yang dikembangkan mencakup pengutipan dengan menggunakan standar APA yang meliputi pengutipan dalam teks, paraphrase dan ringkasan. Sampel pada penelitian ini diambil dengan menggunakan metode purposive sampling. Data diambil dengan menggunakan wawancara, angket dan tes untuk melihat validitas, praktikalitas dan efektifitas produk. Data yang telah dikumpulkan dianalisa secara kuantitatif dan kualitatif. Berdasarkan hasil penelitian, ditemukan bahwa validitas produk sangat tinggi (o.92). Aspek praktikalitas terdiri dari kemudahan, efisiensi dan manfaat, yang terkategori sangat tinggi baik pada kelompok kecil maupun uji lapangan. Efektifitas modul memiliki skor 0.4 yang meingindikasikan peningkatan sedang yang dimiliki mahasiswa sebelum dan setelah perlakuan.
\end{abstract}

\footnotetext{
${ }^{1}$ University Islam Negeri Sulthan Thaha Saifuddin, Jambi, Indonesia

Email: suryanihilma@gmail.com

${ }^{2}$ Institut Agama Islam Negeri Curup, Bengkulu, Indonesia

Email: eka.apriani@iaincurup.ac.id
} 


\section{INTRODUCTION}

Academic writing is a compulsory subject in all English departments. Based on the KKNI curriculum of the English study program, one of the learning outcomes of this subject is to enable the students to write scientific work using APA style reference. In producing scientific work, the students are required to cite sources directly and indirectly. Citing sources indirectly by paraphrasing and summarizing is important for producing authentic scientific work. According to Abdulkareem (2013), paraphrasing and summarizing are techniques that need to be learned and mastered in academic writing. The students should use more indirect quotations (paraphrasing and summarizing) than direct quotations in their scientific work to avoid plagiarism. However, the students still encountered problems in writing good paraphrasing. The writer's preliminary research showed that the students' paraphrasing was categorized as poor for the paraphrasing was very similar to the original passages. Language learners who are inexperienced in academic words generally find it difficult to paraphrase in the second or foreign language (Keck, 2014).

Academic writing is the advanced form of writing learned by second or foreign language learners (Fadda, 2012). Academic writing is a product of the mind. It is a mental and cognitive activity. This course generally discusses the essay and techniques used to write scientific work. Quotations are essential parts of academic writing (Guide, n.d.; Verheijen, 2015). Quotations provide information and ideas the student has gathered from other sources. The students must demonstrate academic honesty by giving documentation to indicate the sources of information.

Indirect quotations include paraphrasing and summarizing. Using more indirect quotations than direct ones in scientific writing is the way for the writers to avoid plagiarism (Silfiani, Aziz \& Daud, 2018). Plagiarism is resulted from the inadequate understanding to do proper citations and notations and unaware of cheating. Teaching students skills related to academic writing such as quoting, citing, paraphrasing, and summarizing are essential to minimize plagiarism.

Some previous studies revealed that the students' difficulties in paraphrasing and paraphrasing source texts include linguistic factors (Dwihandini et al., 2013), writing style the students have and poor reading comprehension skills (O. Alaofi, 2020). Based on the interview done by the researcher, it was found that the students could not produce good paraphrasing and summarizing as they: 1) were unfamiliar with the vocabularies used in the original passage. Most of the passages given in the textbook were not related to their major. The passages concerned with science and social studies, 2) had not had enough practices. The textbook they used only provided a few practices on the citation, and 3) could not write citation based on APA style. The textbook did not include the explanation of citation using APA style. Concerning this problem, it is necessary to develop a module of academic writing that meets students' needs.

A number of studies on plagiarism issues in universities have been conducted. The previous studies revealed that the university students did not acknowledge the authors of the sources in their scientific papers (Anney \& Mosha, 2015; Faizan \& Munshi, 2019; Novawan et al., 2020). They understood that plagiarism is dishonest and broke academic integrity, yet they kept doing it. The students plagiarize on their academic works might be due to the ease of internet access and copying (Šprajc et al., 2017), institution, availability of internet facilities, and personal attitude (Md Salleh, 2011).

Dealing with this issue, it is crucial to develop a learning module on academic writing, specifically on the citation, so the students are able to figure out how to cite properly. There have been several studies conducted to develop a module of writing. (Rofii et al., 2018) carried out a study to develop a contextual-based learning module for an academic writing course to enhance students' writing skills. The module developed integrated seven components of contextual approach in various learning activities. Hendrawaty, Husnaini, and Sundari conducted another research and development study. They developed a competence-based module of writing 1. They modified 
teaching and learning material to attain the appropriateness between indicators and students' competence in Writing 1 from Sentence to Paragraph Module (Hendrawaty et al., 2018).

Concerning the problems found in students' academic writing class, it is essential to develop a module that could assist the students in producing good paraphrasing and citation based on APA style. The previous researchers had not included APA style in paraphrasing and summarizing the sources in the module they developed. The objective of the present study was to produce a valid, practical, and effective academic writing module to be used as teaching and learning material.

\section{METHODS}

This study use to research and development design. The writer employed the model developed by Plomp. The model consists of three stages: preliminary research, development or prototyping, and assessment (Ploomp \& Nieven, 2013). Formative assessments were included in each phase. The formative assessments used in this study include: 1) self-evaluation or screening. The checklist of important characteristics or design specifications was used, 2) expert review. Five experts were involved in this phase to validate and give suggestions on the product developed 3) one-to-one evaluation. Three users were observed and interviewed after using the product in a normal situation, 4) small or micro evaluation. There were 9 students used the products. The evaluator gave the questionnaire to them, 5) field test. The number of students had the treatment to see the product's practicality and effectiveness.

The data of this study were collected by using interviews, validity and practicality questionnaire, and writing tests. The interview data were obtained from students and lecturers related to the academic writing class. The validity questionnaire consisted of four components (content, construction, language, and graphic) to which the experts should respond. A selfevaluation sheet was used to recheck the comprehensiveness of module components and errors in developing the module. The result of self-evaluation was used to revise the module prior to validation by experts. Next, a validity instrument was distributed to find out the validity of the module. Experts responded it. The last technique of collecting data was a writing test. It was distributed before and after the treatment. The test contained the items related to citation, paraphrasing, and summarizing.

In analyzing the data, the researcher employed several techniques. First, experts' data of validity were analyzed using Kappa Cohen. The results were then categorized based on Kappa value by Boslaugh and Paul (2008). The same technique was applied for practicality data. Lastly, the results of students' learning outcomes were analyzed using the formula of Hake. The result was a Gain score or N-Gain.

\section{FINDINGS AND DISCUSSION}

\section{Development or Prototyping Phase}

This prototype was developed in the form of the Academic Writing module, which included the discussions of in-text citation, paraphrasing, and summarizing. The components designed were cover, acknowledgment, table of contents, module instructions, learning materials, worksheet, answer key, and references.

\section{Self-Evaluation Phase}

After the development phase (prototype I) was accomplished, a self-evaluation was conducted to produce prototype II. This phase focused on the obvious errors such as mistyping, the misuse of pictures, the incomplete module components, and citation explanations. Basically, the errors were found in the font size, picture layout, and the consistency of sentences. Prototype II resulted from this phase.

\section{Expert Review and One-to-One Evaluation}

Prototype III has resulted from expert review and one-to-one evaluation on prototype II. Prototype II was validated by experts (English lecturers and IT experts) and evaluated (one-to-one 
evaluation) by three students of the English Department. Four components were validated: content, construct, language, and graphic. The validators gave suggestions on the module. The suggestions are as follows:

a. Synchronizing the font size on the cover
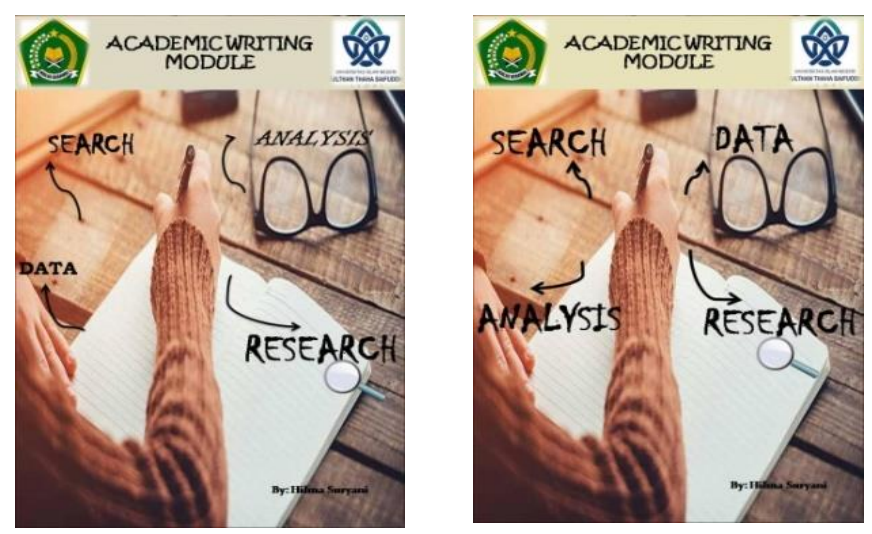

Figure 1. The cover of the module before and after the revision

b. Adding the learning objectives on the discussion of summarizing
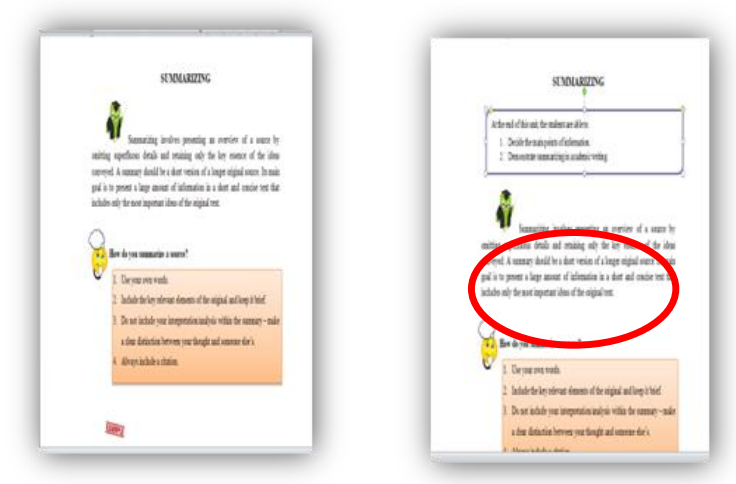

Figure 2. The sheet of the material of summarizing before and after the revision

c. Giving the word 'directions' before the instructions on several worksheets.
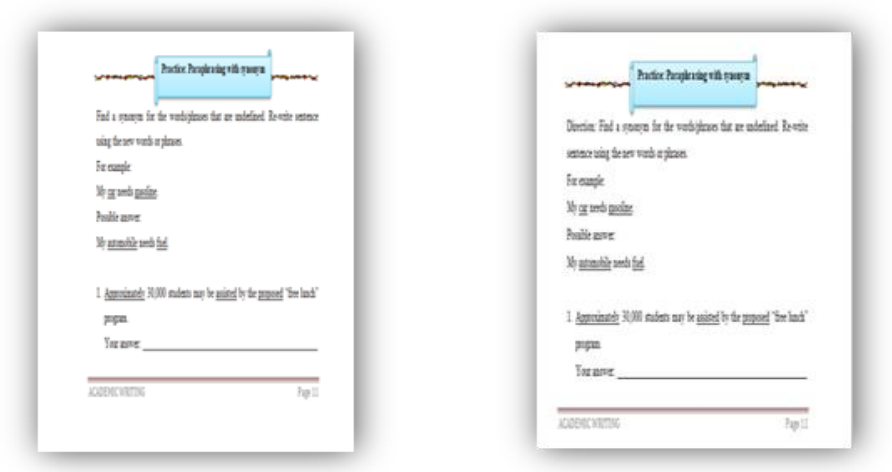

Figure 3. The worksheet before and after the revision 
After the revision, the validators rated the module on the validation sheet. The validation results were then analyzed using moment kappa formulae. Based on the analysis of the four components, the result of validity can be seen in the following table.

Table 1. The Validity of Prototype III

\begin{tabular}{lll}
\hline Aspect & K-value & Category \\
\hline Content & 0.92 & Very high \\
Construct & 0.88 & Very high \\
Language & 0.84 & Very high \\
Graphic & 0.84 & Very high \\
Mean & 0,87 & Very high \\
\hline
\end{tabular}

The one-to-one evaluation was conducted by interviewing 3 students of the fifth semester at English Department, categorized as low achievers, average achievers, and high achievers. There were three aspects evaluated: clarity, appeal, and obvious errors. Based on the interview result, it was found that the cover of the module already represented the content for teaching the citation based on APA style. In addition, the module instructions were understandable, the color and pictures were appealing for the students. As one-to-one evaluation took place, low-achieving students found it difficult to answer the questions in-text citation. Consequently, one of the questions was changed to the easier one.

\section{Small-Group Evaluation}

Small group evaluation was carried out by delivering the citation materials to nine students of semester V at the English Department. They were categorized as high, average, and low achievers. This evaluation aimed to find out the practicality of the module. Those nine students were taught using the module. At the end of the meeting, they were instructed to fill in the questionnaire related to the module in teaching and learning activities. The aspects evaluated in small group evaluation included the ease, time efficiency, and benefits of the module.

The result of practicality showed that the aspect of ease, efficiency, and benefits of the module had very high practicality. Overall, the $k$ value of practicality was 0.85 . The practicality of the module can be seen in the following table.

Table 2. The Practicality of Module in Small Group Evaluation

\begin{tabular}{lll}
\hline Aspect & K-value & Category \\
\hline Appeal & 0.86 & Very high \\
Ease of Use & 0.88 & Very high \\
Time Efficiency & 0.78 & High \\
Benefit & 0.81 & Very high \\
Mean & 0,85 & Very high \\
\hline
\end{tabular}

\section{Assessment Phase}

The assessment phase was conducted in order to see the practicality and effectiveness of the module in the field test. The intervention was given to the fifth-semester students in class $\mathrm{D}$. The practicality of the module was obtained from students' and lecturers' responses on the module. There were two Academic Writing lecturers involved to respond the questionnaire. Both lecturers and students gave their responses once the intervention was finished. 


\section{The Modul Practicality by Students}

Twenty-eight students were given the response on the practicality questionnaire. The mean of kappa value of module practicality was 0.87 indicating high practicality. The practicality of module responded by students in the field test is as follows:

Table 3. The Practicality of Module in the Field Test

\begin{tabular}{lll}
\hline Aspect & K value & Category \\
\hline Appeal & 0.78 & High \\
Ease of Use & 0.75 & High \\
Time Efficiency & 0.70 & High \\
Benefit & 0.72 & High \\
Mean & 0.74 & High \\
\hline
\end{tabular}

\section{The Modul Practicality by Lecturers}

Two Academic Writing lecturers responded to the practicality questionnaires. They responded to the questionnaire when the researcher finished the treatments. The mean of kappa value on practicality was 0.85 , which means the module had very high practicality. It indicated that the Academic Writing module that the researcher developed was practical.

Table 4. The Practicality of Module by the Lecturers

\begin{tabular}{lll} 
Aspect & K value & Category \\
\hline Appeal & 1.00 & Very High \\
Ease of Use & 0.85 & Very High \\
Time Efficiency & 0.86 & Very High \\
Benefit & 0.88 & Very High \\
Mean & 0.85 & Very High \\
\hline
\end{tabular}

In addition to finding out the practicality of the module, the field test was conducted to see the effectiveness. The students were given pretest and posttest.

Table 5. The Result of Students' Learning Outcome in the Field Test

\begin{tabular}{|c|c|c|c|}
\hline \multirow[t]{2}{*}{$\overline{\mathbf{N}}$} & \multicolumn{2}{|c|}{ Mean } & \multirow{2}{*}{ Gain Category } \\
\hline & Pretest & Posttest & \\
\hline 31 & 57 & 76 & 0,4 Average \\
\hline
\end{tabular}

Table 5 showed that the mean score of the students after the intervention was 0.4 which indicated the average improvement.

\section{Discussions}

The research and development is conducted by the researcher aimed to produce the product in the form of the module of Academic Writing for the fifth-semester students of the English Department. The data used were validity questionnaires, practicality questionnaires, and tests. Each data used could produce a good quality module. A product is said to have good quality if the validity, practicality and effectiveness are met (Kadir et al., 2019; Plomp, 2013). Validity, practicality and effectiveness test is essential since the teaching material can be used in the teaching and learning process when those three elements are tested (Akker, 2006). 
The validity questionnaire consisted of 21 statements covering the components such as content, construct, language and graphic. The validity of those four aspects was categorized very high. The kappa value was 0.92. The category indicated that the Academic Writing module was in line with the learning outcomes and indicators attained. The module contains learning materials such as in-text citation, paraphrasing and summarizing, which had been acceptable in accordance with English discipline and the demands of curriculum KKNI. Moreover, the assessment given in each unit had directed the students to cite using APA style. It is congruent with Rochmad (2012) stated that the validity showed the product is in line with the curriculum and based on a strong theoretical rationale.

The construct validity of the module had a very high category. It indicated that the materials presented in order based on the learning outcomes that have been formulated so there is an interrelation among the concepts learned. It is in line with Rohmad that the construct validity of a product demonstrates various components interrelated and connected consistently. A product is said to be valid in terms of construct aspect if all of the components are consistently interrelated (Plomp and Nieveen, 2013).

In the language validity, the module had a very high kappa value. This category indicated that the module used the appropriate and acceptable language. It is in line with Depdiknas (2008) that the language of a product is rated in terms of readability, clarity of the information, grammaticality, and the use of efficient and effective language.

In terms of the graphic aspect of the module, the validity was very high. This category indicated that the font size is varied, the layout, pictures, illustration are appealing. The pictures and visual symbols used in the module assisted the students in comprehending the concept (Ellizar, 2009). The indicators that should be considered in graphic aspects include the layout and color of the pictures, illustration, or product photos (Depdiknas, 2008).

The practicality is assessed in terms of three aspects: ease of use, time efficiency, and the benefit of the module. The module is said to be practical if the lecturer and the user representatives could use the product easily (Plomp and Nieveen, 2013). The practical teaching material can be employed to run the instruction logically without any significant problems. The practicality of the Academic Writing module, based on the result of practicality questionnaires in small group evaluation and field test, was high.

The effectiveness of the module was determined by the learning outcomes of the students after they were given the intervention. The average improvement attained by the students based on the gain score indicated that the module could be used as the learning material. Learning materials are said to be effective if using them. The learning outcomes demonstrate: 1) students are able to master the learning materials and 2) students show a positive attitude to learning (Putri et al., 2019).

\section{CONCLUSION}

Concerning the effectiveness analysis, it was found out that the academic writing module could improve students' learning outcomes. It can be seen from the result of pre-test post-test of the participants. The gain score indicated the improvement was at the level of average. It can be said that the developed academic writing module is effectively used in learning the citation of APA style. The validity test was carried out by giving the questionnaires to the students and lecturers. The mean scores fell on the very high validity. Similarly, based on the practicality questionnaires distributed in small group and field test, the mean scores were also categorized very high. Hence, it can be concluded that the developed Academic Writing module is valid, practical, and effective to use. This study is limited to the students at one state university. It is hoped that further studies can include a larger sample so the product can be representative to be used as a teaching tool. The current study has a positive impact as a reference for both lecturers and students to reduce plagiarism. 


\section{REFERENCES}

Abdulkareem, M. N. (2013). An investigation study of academic writing problems faced by arab postgraduate students at Universiti Teknologi Malaysia (UTM). Theory and Practice in Language Studies, 3(9), 1552-1557. https://doi.org/10.4304/tpls.3.9.1552-1557

Akker, J. Van Den. (2006). Curriculum_design_research_Van_der_Akker.37-50.

Anney, V. N., \& Mosha, M. A. (2015). Student's Plagiarisms in Higher Learning Institutions in the Era of Improved Internet Access: Case Study of Developing Countries. Journal of Education and Practice, 6(13), 203-216. https://eric.ed.gov/?id=EJ1080502 on 10th August 2015.

Boslaugh, Sarah and Watters, Paul Andrew. (2008). Statistics in a Nutshell, a Desktop Quick Reference. (Beijing, Cambridge, Famham, Köln, Sebastopol, Taipei,Tokyo: O’reilly, 2008)

Departemen Pendidikan Nasional. Pengembangan Bahan Ajar dan Media. Jakarta: Departemen Pendidikan Nasional, 2008).

Dwihandini, L. A., Marhaeni, A. A. I. N., \& Suarnajaya, I. W. (2013). The Analysis of the Factors Affecting Undergraduate Students ' Difficulties in Writing Thesis in the English Department of Mahasaraswati. E-Journal Program Pascasarjana Universitas Pendidikan Ganesha, 2, 1-12. pasca.undiksha.ac.id/e-journal/index.php/jurnal_bahasa/article/view/903

Ellizar. (2009). Models of teaching by constructivism approach with module. Jurnal Kependidikan Triadik. Vol. 12, No. 1, April 2019, pp. 7-16.

Fadda, H. Al. (2012). Difficulties in academic writing: From the perspective of King Saud University postgraduate students. English Language Teaching, 5(3), 123-130. https://doi.org/10.5539/elt.v5n3p123

Faizan, M., \& Munshi, S. A. (2019). Plagiarism , a Critical Issue in Academic Research Integrity : Attitudes of. 12th International CALIBER-2019, 322-336.

Guide, L. (n.d.). To Paraphrase or to Quote?

Hendrawaty, N., Febriyanti, R. H., \& Sundari, H. (2018). Pengembangan Materi Ajar Berbasis Kompetensi Untuk Mata Kuliah Writing 1. Faktor Jurnal Ilmiah Kependidikan, 5(3), 199212.

Kadir, J. S., Zaim, M., \& Refnaldi, R. (2019). Developing Instruments for Evaluating Validity, Practicality, and Effectiveness of The Authentic Assessment for Speaking Skill at Junior High School. May. https://doi.org/10.2991/icoelt-18.2019.14

Keck, C. (2014). Copying, paraphrasing, and academic writing development: A re-examination of L1 and L2 summarization practices. Journal of Second Language Writing, 25(1), 4-22. https://doi.org/10.1016/j.jslw.2014.05.005

Md Salleh, M. H. (2011). Academic Dishonesty: Factors That Contribute Plagiarism in a Technical College in Malaysia. Polimas.Edu.My, 2006, 1-10. http://www.polimas.edu.my/web4/images/penerbitan/prosiding2011/jpa harris.pdf

Novawan, A., Aisyiyah, S., Miqawati, A. H., Wijayanti, F., \& Indrastana, N. S. (2020). JER| Journal of ELT Research. 5(1), 80-93. https://doi.org/10.22236/JER

O. Alaofi, A. (2020). Difficulties of Summarizing and Paraphrasing in English as a Foreign Language (EFL): Saudi Graduate Students' Perspectives. International Journal of English Language Education, 8(2), 193. https://doi.org/10.5296/ijele.v8i2.17788

Plomp. (2013). Educational Design Research Educational Design Research. Educational Design Research, 1-206. http://www.eric.ed.gov/ERICWebPortal/recordDetail?accno=EJ815766

Ploomp, Tjeerd and Nienke Nieveen. Part A: Educational Design Research: An Introduction. (Netherlands: SLO, 2013)

Putri, S. K., Hasratuddin, H., \& Syahputra, E. (2019). Development of Learning Devices Based on Realistic Mathematics Education to Improve Students' Spatial Ability and Motivation. International Electronic Journal of Mathematics Education, 14(2), 243-252. https://doi.org/10.29333/iejme/5729 
Rochmad. (2012). Desain model pengembangan perangkat pembelajaran matematika. Jurnal Matematika Kreatif-Inovatif, Vol. 3, No. 1, Juni 2012, h. 59-72.

Rofii, A., Murtadho, F., \& Rahmat, A. (2018). Model of Contextual-Based Academic Writing Learning Module. English Review: Journal of English Education, 6(2), 51. https://doi.org/10.25134/erjee.v6i2.1242

Silfiani, Aziz, Zulfadli. A. and Daud, Bukhari. Plagiarism in English academic writing: Students' perception. English Education Journal, Vol. 9, No. 1, January 2018, pp. 101-123.

Šprajc, P., Urh, M., Jerebic, J., Trivan, D., \& Jereb, E. (2017). Reasons for plagiarism in higher education. Organizacija, 5o(1), 33-45. https://doi.org/10.1515/orga-2017-0002

Verheijen, L. (2015). The language of quoting in academic writing. Dutch Journal of Applied Linguistics, 4(1), 101-121. https://doi.org/10.1075/dujal.4.1.10ver 